\title{
APPLICATION OF NATURAL ZEOLITE FOR INTENSIFICATION OF MUNICIPAL WASTEWATER TREATMENT
}

\author{
Kairat Ospanov ${ }^{1}$, Menlibai Myrzakhmetov' ${ }^{1}$, Dariusz Andraka², Lech Dzienis ${ }^{2}$ \\ 1 Kazakh National Technical University, Department of Engineering Systems and Environment Protection, \\ 050013 Almaty, Kazakhstan; e-mail: ospanovkairat@mail.ru, myrzahmetov@mail.ru \\ 2 Faculty of Civil and Environmental Engineering, Bialystok University of Technology, 15-351 Bialystok, Poland; \\ e-mail: d.andraka@pb.edu.pl, I.dzienis@pb.edu.pl
}

Received: 2016.08.16

Accepted: 2016.09.26

Published: 2016.11.01

\begin{abstract}
The purpose of this research was to prove that a hybrid system including activated sludge and biofilm attached to carrying media (natural zeolite) can improve the efficiency of municipal wastewater treatment. The study was performed using a pilotscale plant installed on Almaty Wastewater Treatment Plant (Kazakhstan) and treated sewage after preliminary mechanical treatment. The investigations were conducted in 2 stages: with installation without packing media (activated sludge only) and packed with zeolite from Chankanaysky field (activated sludge and biofilm). The results from the study showed a significant improvement of treatment efficiency for all examined parameters ( $\mathrm{BOD}_{5}, \mathrm{COD}$, suspended solids, nitrogen compounds and phosphates). Microbiological examination of biomass from the bioreactor indicated high diversity and activity of identified species, proving good conditions for both activated sludge and biofilm.
\end{abstract}

Keywords: natural zeolite, hybrid systems, attached-suspended growth systems, wastewater treatment, nitrogen removal

\section{INTRODUCTION}

Protection of water resources from contamination related to human activities is one of the key environmental problems in contemporary world. Discharge of inadequately treated or untreated wastewater to the surface waters contributes the most to their poor quality [Baekenova, 2011].

Present-day technologies of wastewater treatment tend to focus on different priorities than several years ago. Classic mechanical and biological processes which showed high efficiency in the removal of mainly organic carbon and suspended solids are nowadays the subject of different modifications aimed at the intensification of biochemical processes that would enhance removal of biogenic substances like nitrogen and phosphorus compounds. Those improvements include the implementation of microbiological processes of nitrification, denitrification and dephosphata- tion, using either retrofitted existing installations or building completely new technological lines. Depending on the local requirements, new technologies should assure effluent quality standards preventing degradation of receiving waters and reducing the risk of eutrophication.

Nowadays in Kazakhstan, as in many other developing countries, most of centralized wastewater treatment systems use activated sludge technology utilized in aerobic continuous flow reactors. Therefore, possible methods of modification of technologies based on suspended growth systems should be a foreground target for researches in a field of wastewater treatment [Programma “AK Bulak", 2011].

Back in the 1960's, experimental researches of the possibility to intensify the biological treatment processes by attached biocenosis were carried out. It was proven that the activity of immobilized biocenosis significantly exceeded the 
oxidizing ability of free-floating sludge [Slovcov 2008]. Different modifications of activated sludge process, called integrated fixed-film activated sludge (IFAS), were developed by adding biofilm attachment surfaces to suspended-growth reactors, thereby creating hybrid suspended/ attached-growth systems [Kim et al., 2011]. As demonstrated by Randall and Sen [1996] IFAS may increase total microbial population without the need for expanding existing facilities and has been shown to be effective at improving nitrification through the enrichment of nitrifying populations in the attached phase.

Yeon et al. [2011] were conducting experiments with activated sludge reactors operating in a batch mode, filled with packing media of different volume (0 to $6 \%$ ) to compare attached and suspended growth systems. Their research proved that increasing the packing ratio can both increase the attached biomass ratio and the capacity of total biomass, thus increasing the possibility of denitrification. It was also observed that settling capacity of the sludge was better in the reactor with attached biofilm. Hence, the hybrid activated sludge systems packed with media supporting biofilm can be a cost-effect option for retrofitting wastewater treatment plants to sustain nitrification, without significantly increasing the suspended growth concentration, and, therefore, without increasing reactor or clarifier volumes [Sriwiriyarat et al., 2005].

Thus, the use of packing media for immobilization of the active biomass attached to their surface opens up new possibilities for optimizing operation of biological processes, not only for their intensification, but also for achievement of better results of wastewater treatment. Both synthetic and natural materials that are capable of attaching biofilm to its surface while filling the volume of biological reactor uniformly may be used as the packing.

Packing media should satisfy a number of requirements, among them the high resistance to corrosion, good mechanical strength, large free passage diameter (low hydraulic resistance), resistance to clogging or plugging and high specific surface area are most important. Especially the extended biologically active area, where various microorganisms necessary to maintain technological goals are fixed, is of crucial importance.

There are many types of packing media available on the market today and different variations of technological processes in which a fixed pack- ing material is placed inside the aeration tank of activated sludge system. For example, in the KALDNES ${ }^{\circledR}$ process (moving-bed biofilm reactor MBBR) small cylindrical-shaped polyethylene carrier elements with density of $0.96 \mathrm{~g} /$ $\mathrm{cm}^{3}$ are used. The packing may fill 25 to $50 \%$ of the tank volume. On the other hand, the BIOSTYR $^{\circledR}$ process (upflow submerged attached growth system) uses $2-4 \mathrm{~mm}$ polystyrene beads with specific area ca $1000 \mathrm{~m}^{2} / \mathrm{m}^{3}$. The bed may operate both in aerobic and anoxic conditions [Metcalf and Eddy, 2003].

Numerous researches have shown a wide area of possible applications of natural zeolites in water and wastewater treatment. Due to their porous structure and valuable physicochemical properties, such as cation exchange, molecular sieving, catalysis etc., the application of zeolites is still a promising technique in environmental cleaning processes [Wang \& Peng, 2009]. It is well documented that zeolite has a high affinity for ammonium and can be used as an efficient sorbent for ammonium nitrogen removal from wastewater [Green et al., 1996; Karapinar, 2009] and reject waters from sludge treatment [Piaskowski and Nowak, 2012]. Additionally, possible applications of natural zeolite for intensification of ammonia nitrogen removal in activated sludge systems by adding powdered zeolite as bio-flocculant were studied [Jung et al., 1999, 2003]. However, there is still lack of investigations of the possible application of natural zeolite as a carrier of the biofilm in the hybrid attached/ suspended growth systems and its influence on the efficiency of wastewater treatment.

The purpose of this study was to determine influence of packing media of natural zeolite (derived from Chankanaysky field in Kazakhstan) on intensification of biochemical processes in the installation based on activated sludge system, located in Almaty Wastewater Treatment Plant (WWTP), in real operating conditions.

\section{MATERIALS AND METHODS}

\section{Characteristic of natural zeolite from Kazakhstan}

There are many natural zeolites identified in the world. They are hydrated aluminosilicate minerals with a structure composed of three main components: aluminosilicate framework, exchange- 
able cations and zeolitic water, and proportions between those components are strongly dependent on the geographic location of the minerals.

The main physical and chemical characteristics of natural zeolite from the Chankanaysky field are provided in Table 1.

Comparing to other conventional granular materials, the zeolite has a higher porosity and specific surface. During exploitation it does not substantially change its properties and can be easily recovered and reused.

\section{Pilot-scale plant overview}

According to the objective of the research, pilot plant installation was built at Almaty WWTP

Table 1. Main physical and chemical properties of Kazakhstan natural zeolite

\begin{tabular}{|l|c|}
\hline \multicolumn{1}{|c|}{ Parameter } & Characteristics \\
\hline Appearance & $\begin{array}{c}\text { Russet and grey } \\
\text { colors }\end{array}$ \\
\hline Mass fraction of zeolite, \% & $50-84$ \\
\hline Mineral form & Clinoptilolite \\
\hline Mohs hardness & 4.5 \\
\hline Associated minerals, \%: & $24-30$ \\
\hline - quartz and feldspar & $3.0-6.0$ \\
\hline - clay minerals & $0.5-2.0$ \\
\hline - dolomite & $0.75-1.25$ \\
\hline $\begin{array}{l}\text { Absorption capacity } \\
\text { for ammonium ion }\end{array}$ & $1.17-1.32$ \\
\hline Bulk density, g/cm ${ }^{3}$ & $2.18-2.50$ \\
\hline Real density, g/cm ${ }^{3}$ & $150-220$ \\
\hline Mechanical crushing strength, $\mathrm{kg} / \mathrm{cm}^{2}$ & $>99 \%$ \\
\hline Water resistance, \% & \\
\hline
\end{tabular}

to conduct field experiments. The scheme of installation is shown in Figure 1.

Maximum capacity of the installation is $1-1.5 \mathrm{~m}^{3} / \mathrm{h}$. After preliminary mechanical treatment at Almaty WWTP facilities, wastewater is pumped with the pipeline of $25 \mathrm{~mm}$ diameter to a raw sewage storage with the capacity of $0.1 \mathrm{~m}^{3}$ and then by gravity fed to the activated sludge tank with the volume of $3.0 \mathrm{~m}^{3}$, which is supplied with air from the main air ducts of Almaty WWTP. After sedimentation in the clarifiers, the treated wastewater is collected in the final storage.

Preliminary investigations with this installation were carried out in 1997 - 2001 using 10 $\mathrm{cm}$ thick shelf which was covered with wire mesh from both sides and filled with natural zeolite. The shelf with zeolite packing was located at the level of $0,8 \mathrm{H}(\mathrm{H}-$ the height of the tank). The experimental data acquired from that research have shown promising results. However, after a long time of operation of the installation, secondary pollution and increased removal of sludge from the clarifier were observed. Therefore, additional electro-coagulation was implemented to achieve required quality of the effluent. On the basis of those experiments, series of technical installation for municipal wastewater treatment with capacity $24-96 \mathrm{~m}^{3} / \mathrm{d}$ was developed and patented [Myrzakhmetov and Ospanov, 2011].

Taking into consideration all of the above mentioned shortcomings, installation shown in Figure 1 was remodelled in 2009 and equipped with a new shelf with the dimensions of $35 \times 52 \times 16.5$ $\mathrm{cm}$. The shelf was covered with metal grid from the top and the bottom and located $40 \mathrm{~cm}$ above

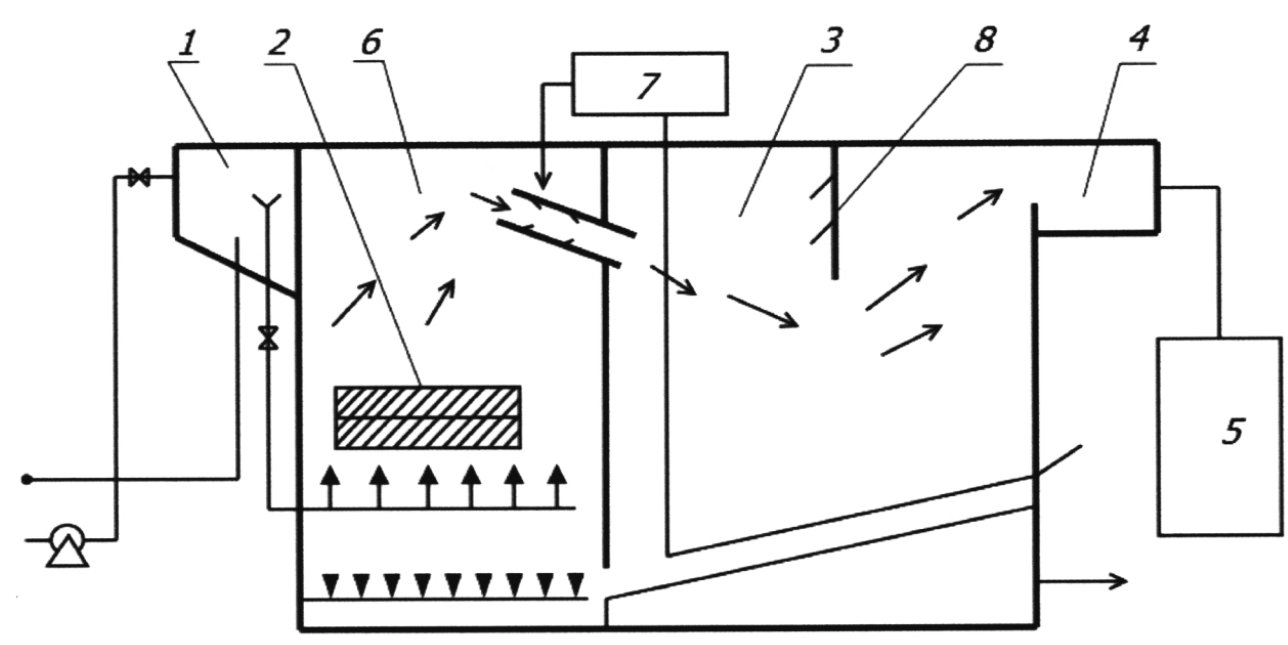

Figure 1. Scheme of experimental installation: 1 - raw wastewater storage, 2- zeolite packing, 3-clarifier, 4 - discharge pocket, 5 - discharge storage; 6 - aerobic tank; 7 - airlift; 8 - deflector 
bottom of the tank. The packing of natural zeolite consisted of three $5.5 \mathrm{~cm}$ thick cassettes, the distance between them was $7 \mathrm{~cm}$, which covered $20 \%$ of the total volume of the aeration tank (estimated as optimum load of zeolite packing during earlier experiments). After passing the aerobic activated sludge tank loaded with zeolite, wastewater goes to the secondary clarifier and then is discharged to the final storage.

\section{Sampling and analysis}

Physico-chemical and sanitary analyses for monitoring of the installation operation were executed in compliance with the standard certified methods, in the laboratory of Almaty WWTP. Chemical analyses included the following parameters: biological oxygen demand $\left(\mathrm{BOD}_{5}\right)$, total suspended solids (TSS), phosphates (P$\mathrm{PO}_{4}$ ), ammonium nitrogen $\left(\mathrm{N}-\mathrm{NH}_{4}\right)$, nitrite $(\mathrm{N}-$ $\left.\mathrm{NO}_{2}\right)$, nitrate $\left(\mathrm{N}^{-\mathrm{NO}_{3}}\right)$ and dissolved oxygen (DO). Activated sludge was evaluated by the following parameters: mixed liquor suspended solids - MLSS, sludge index and volatile solids (MLVSS - measured as a percent of total MLSS). Also microbiological analysis of activated sludge was performed in the samples collected in different zones of the reactor.

\section{RESULTS AND DISCUSSION}

The study was conducted on Almaty WWTP in 2009-2011, using wastewater that has passed preliminary mechanical treatment. During this period, 14 experiments, lasting $1-6$ days each, were carried out.

The influent to the pilot plant was characterized by the following parameters (mean values): COD $-187.1 \mathrm{mg} / \mathrm{dm}^{3}, \mathrm{BOD}_{5}-84.6 \mathrm{mg} / \mathrm{dm}^{3}$, TSS $-101.6 \mathrm{mg} / \mathrm{dm}^{3}$, ammonium nitrogen $-24.3 \mathrm{mg} /$ $\mathrm{dm}^{3}$, nitrite nitrogen $-0.06 \mathrm{mg} / \mathrm{dm}^{3}$, nitrate nitrogen $-0.19 \mathrm{mg} / \mathrm{dm}^{3}$, total phosphorus (as phosphates) $-7.2 \mathrm{mg} / \mathrm{dm}^{3}$.

At the first stage of the study, pilot plant worked without packing media, in order to determine its main technological parameters and to obtain a reference set of results. The full biological treatment of influent was achieved at this period, resulting in the concentration of $\mathrm{BOD}_{5}$ and total suspended solids in the effluent at the level of $10-15 \mathrm{mg} / \mathrm{dm}^{3}$, while the nitrates concentration was $24 \mathrm{mg} / \mathrm{dm}^{3}$.
The second stage of research included series of experimental runs with installation packed with zeolite bed that constituted $20 \%$ of reactor's volume. Summarized results of the study are provided in Table 2 and detailed results of the second stage of experiments - in Table 3.

All of 14 runs of experiment in second stage of the study were conducted in relatively stable conditions regarding hydraulic load (11.0 - 12.1 $\left.\mathrm{m}^{3} / \mathrm{d}\right)$, temperature $\left(20-22^{\circ} \mathrm{C}\right.$ for inflowing sewage), dissolved oxygen in aerobic zone $(2.2-3.1$ $\mathrm{mg} / \mathrm{dm}^{3}$ for most of the runs, except runs 6,12 , 14 when DO was $3.7-4.0 \mathrm{mg} / \mathrm{dm}^{3}$ ), and biomass concentration (MLSS in the range $3.2-4.3 \mathrm{~kg} / \mathrm{m}^{3}$ with $67-70 \%$ of VSS). Moreover, the quality of inflowing wastewater did not change significantly, as shown in the box-plot in Figure 2.

It is clearly seen from the results obtained in the second stage of experiment that zeolite packing improved overall efficiency of the pilot plant. As seen in the Figure 3, removal efficiency of organic compounds was $79.5-95.8 \%$ for BOD5 (comparing with $86.5 \%$ for the first stage of the experiment), of total suspended solids $93.7-96.9 \%$ ( 87.5 in the $1^{\text {st }}$ stage), of ammonia nitrogen $79.7-92.7 \%$ (57.6\% in the $1^{\text {st }}$ stage). It can be also observed in Figure 3 that there is no significant correlation between the variations in influent quality and removal efficiency. Despite these variations, the process of removal organic and biogenic compounds is stable as shown in Figure 4 presenting box-plot for removal efficiencies of TSS, $\mathrm{BOD}_{5}, \mathrm{COD}$ and $\mathrm{N}-\mathrm{NH}_{4}$. Ana-

Table 2. Summarized results from the pilot plant

\begin{tabular}{|c|c|c|}
\hline \multirow[b]{2}{*}{ Parameter } & \multicolumn{2}{|c|}{ Stage of the experiment } \\
\hline & $\begin{array}{c}1^{\text {st }} \text {, without } \\
\text { packing }\end{array}$ & $\begin{array}{c}2^{\text {nd }} \text {, with zeolite } \\
\text { packing }\end{array}$ \\
\hline \multicolumn{3}{|l|}{ TSS } \\
\hline effluent, $\mathrm{mg} / \mathrm{dm}^{3}$ & 12.7 & 4.7 \\
\hline removal efficiency, $\%$ & 87.5 & 95.3 \\
\hline \multicolumn{3}{|l|}{$\mathrm{BOD}_{5}$} \\
\hline effluent, mg/dm ${ }^{3}$ & 11.4 & 4.8 \\
\hline removal efficiency, $\%$ & 86.5 & 94.3 \\
\hline \multicolumn{3}{|l|}{$\mathrm{N}-\mathrm{NH}_{4}$} \\
\hline effluent, $\mathrm{mg} / \mathrm{dm}^{3}$ & 10.3 & 3.3 \\
\hline removal efficiency, $\%$ & 57.6 & 86.4 \\
\hline \multicolumn{3}{|l|}{$\mathrm{N}-\mathrm{NO}_{3}$} \\
\hline effluent, $\mathrm{mg} / \mathrm{dm}^{3}$ & 24.0 & 3.8 \\
\hline \multicolumn{3}{|l|}{$\mathrm{N}-\mathrm{NO}_{2}$} \\
\hline effluent, mg/dm ${ }^{3}$ & 0.33 & 0.03 \\
\hline \multicolumn{3}{|l|}{$\mathrm{P}_{-} \mathrm{PO}_{4}$} \\
\hline effluent, mg/dm & 3.1 & 1.2 \\
\hline removal efficiency, \% & 56.9 & 83.3 \\
\hline
\end{tabular}


Table 3. Results from pilot plant with zeolite packing media ( $2^{\text {nd }}$ stage of experiment)

\begin{tabular}{|c|c|c|c|c|}
\hline Parameter & \multicolumn{2}{|c|}{ Range } & \multicolumn{2}{|c|}{ Mean } \\
\hline Flow, $\mathrm{m}^{3} / \mathrm{d}$ & \multicolumn{2}{|c|}{$11.0-12.1$} & \multicolumn{2}{|c|}{11.7} \\
\hline $\mathrm{DO}^{1}, \mathrm{mg} / \mathrm{dm}^{3}$ & \multicolumn{2}{|c|}{$2.2-4.0$} & \multicolumn{2}{|c|}{2.9} \\
\hline $\mathrm{MLSS}^{1}, \mathrm{~kg} / \mathrm{m}^{3}$ & \multicolumn{2}{|c|}{$3.2-4.3$} & \multicolumn{2}{|c|}{3.8} \\
\hline \multirow[t]{3}{*}{ MLVSS $1, \%$} & \multicolumn{2}{|c|}{$67-70$} & \multicolumn{2}{|c|}{68.4} \\
\hline & \multicolumn{2}{|c|}{ Influent } & \multicolumn{2}{|c|}{ Effluent } \\
\hline & Range & Mean & Range & Mean \\
\hline Temperature, ${ }^{\circ} \mathrm{C}$ & $20-22$ & 20.9 & $16-24$ & 19.6 \\
\hline TSS, mg/dm ${ }^{3}$ & $73.4-169.7$ & 102.3 & $3.2-7.6$ & 4.6 \\
\hline $\mathrm{BOD}_{5}, \mathrm{mg} / \mathrm{dm}^{3}$ & $65.3-116.3$ & 76.2 & $3.0-14.3$ & 5.0 \\
\hline $\mathrm{COD}, \mathrm{mg} / \mathrm{dm}^{3}$ & $135.3-178.5$ & 157.5 & $5.4-27.4$ & 16.3 \\
\hline $\mathrm{N}-\mathrm{NH}_{3}, \mathrm{mg} / \mathrm{dm}^{3}$ & $19.8-30.8$ & 22.9 & $1.7-4.8$ & 3.2 \\
\hline $\mathrm{N}-\mathrm{NO}_{2}, \mathrm{mg} / \mathrm{dm}^{3}$ & & & $0.2-1.0$ & 0.6 \\
\hline $\mathrm{N}-\mathrm{NO}_{3}, \mathrm{mg} / \mathrm{dm}^{3}$ & & & $1.7-4.3$ & 3.4 \\
\hline $\mathrm{P}-\mathrm{PO}_{4}, \mathrm{mg} / \mathrm{dm}^{3}$ & & & $0.33-1.8$ & 0.7 \\
\hline
\end{tabular}

1) in aerobic zone

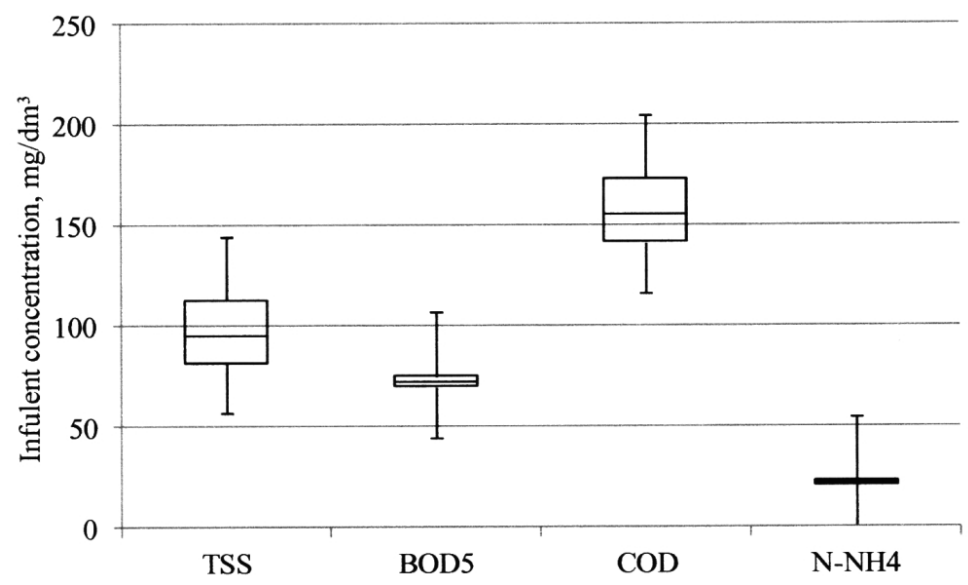

Figure 2. Box-plot of influent concentrations during $2^{\text {nd }}$ stage of experiment
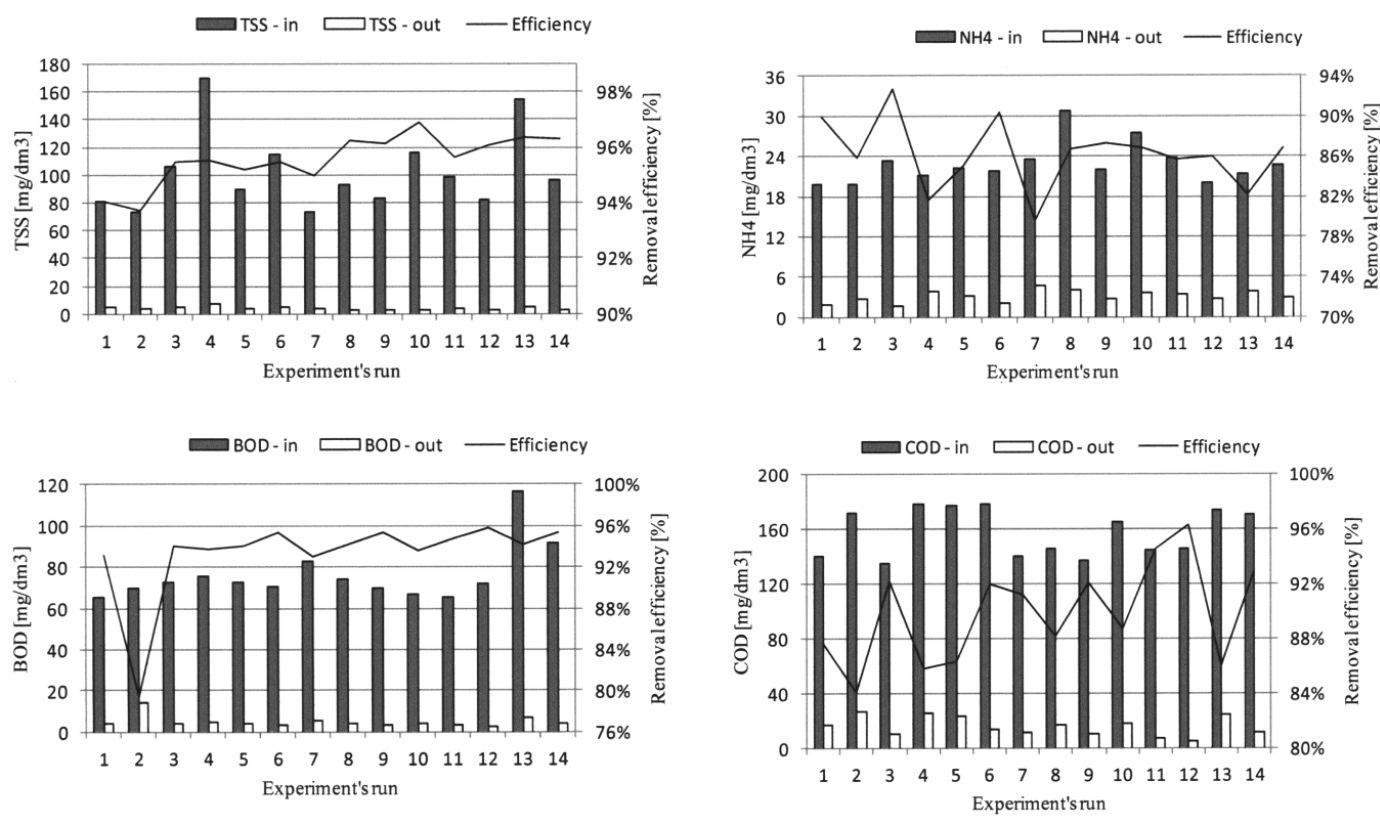

Figure 3. Effluent concentrations and pilot plant efficiency for selected parameters (reactor with zeolite). 


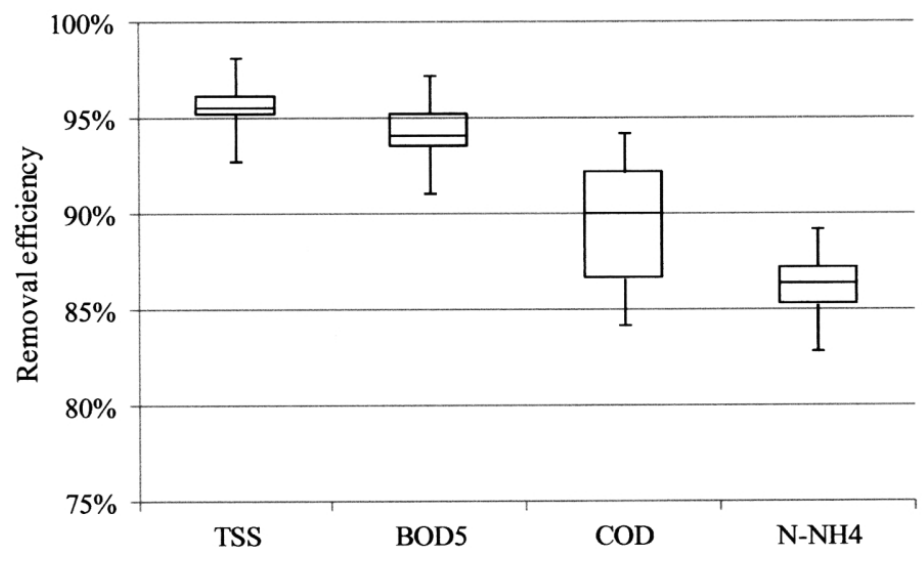

Figure 4. Box-plot for removal efficiency of pilot plant for selected parameters (reactor with zeolite)

lyzing results showing effluent concentration of the other biogenic compounds $\left(\mathrm{N}-\mathrm{NO}_{2}, \mathrm{~N}^{-\mathrm{NO}_{3}}\right.$ and $\mathrm{P}_{-} \mathrm{PO}_{4}$ in Table 3), it can be also stated that the processes of nitrification, denitrification and dephosphatation are sufficiently stable and more efficient than in the reactor without zeolite packing (first stage).

Together with the chemical analysis of treated sewage, the microbiological examination of activated sludge flocks was also performed. During the first stage of experiment, microscopic analysis of activated sludge demonstrated a dominant occurrence of protozoa species, mostly similar to Arcella species, which is a good indicator of a reactor where nitrification process is achieved. For the second stage, microbiological structure of the biomass was significantly different, mostly due to existence of separated anoxic and aerobic zones, and the presence of biofilm in the reactor. The comparison of microbiological properties of both zones in the reactor during the second stage of research is presented in Table 4.

It was also interesting, that multicellular worms - Nematodes -were observed in the biofilm sampled from zeolite packing. Typically, these organisms live in environments with low oxygen content. This fact indicates presence of anoxic conditions in the neighborhood of zeolite packing, which enhance denitrification process. It can be also stated, that the composition of biofilm attached to zeolite packing is compatible with biofilters.

\section{CONCLUSIONS}

The results of studies carried out on pilot plant installation packed with natural zeolite proved feasibility and efficiency of this type of packing for the improvement of wastewater treatment in suspended growth systems. Experimental investigations demonstrated higher efficiency of hybrid installation (with biofilm attached to natural zeolite carrier), especially in removal of nitrogen compounds, than the standard installation with activated sludge. This is particularly important when considering improvement of existing wastewater treatment plants for the protection of receiving waters against eutrophication.

Table 4. Microbiological characteristics of biomass in the reactor ( $2^{\text {nd }}$ stage of experiment)

\begin{tabular}{|l|c|c|}
\hline \multirow{2}{*}{ Species } & \multicolumn{2}{|c|}{ Description } \\
\cline { 2 - 3 } & anoxic zone & aerobic zone \\
\hline Arcella vulgaris & single spec. & active \\
\hline Vorticella convallaria & immobile & active \\
\hline Aspidiscaturrida & immobile & active \\
\hline Notommata ansata & weakly active & active \\
\hline Opercularia & - & active \\
\hline Vorticella sp. & - & active \\
\hline Cathyphaluna & weakly active & active \\
\hline Callidinavorax & immobile & active \\
\hline Epistylisplicatilis & weakly active & active, big spec. \\
\hline Notommata & weakly active & \\
\hline
\end{tabular}


The composition and physical properties of natural zeolite from Chankanaysky field (Kazakhstan) meet all the requirements for the packing media used in the attached growth and hybrid systems, providing extended specific surface for the biofilm attachment. The biocenosis attached to the carrier may considerably increase the total biomass in the system and improve composition of the activated sludge, thereby giving the possibility of regulating the rate of biochemical processes by adjusting the concentration of sludge in the system and ensuring more reliable operation of treatment facilities.

Microbiological examination of biomass sampled from pilot plant showed that biocenosis in the bioreactor is stable and diversified, thereby indicates that investigated hybrid system with activated sludge and zeolite packing is suitable for the treatment of communal wastewater.

\section{Acknowledgements}

Authors highly appreciate support of the Ministry of Education and Science of the Republic of Kazakhstan. This work was performed under the program: "Scientific and technical activities"/ sub-program: "Grant financing of scientific researches" for 2012 - 2014/ grant: "Creation of innovative technologies of cleaning and utilization of wastewater considering climatic conditions of the Republic of Kazakhstan". This work is also the result of cooperation between Bialystok University of Technology and Kazakh National Technical University and was accomplished under BUT Rector's grant S/WBIIS/2/14, supported by Polish Ministry of Science and Higher education.

\section{REFERENCES}

1. Baekenova M.K. (ed.) 2011. Nacional'nyj doklad o sostojanii okruzhajushhej sredy v Respublike Kazahstan v 2010 godu (Republic of Kazakhstan State of Environment 2011. National Report). Kazakh Research Institute for Ecology and Climate of the Ministry of Environment Protection of the Republic of Kazakhstan, Almaty.

2. Green M., Adriaan M., Lahav O. and Sheldon T. 1996. Biological-ion exchange process for ammonium removal from secondary effluent. Water Sci. Technol. 34 (1-2), 449-458.

3. Jung J.Y., Pak D., Shin H.S., Chung Y.C. and Lee S.M. 1999. Ammonium exchange and bioregeneration of bio-flocculated zeolite in a sequencing batch reactor. Biotechnol. Lett. 21(4), 289-292.
4. Jung J.Y., Chung YC., Shin H.S. and Son D.H. 2004. Enhanced ammonia nitrogen removal using onsistent biological regeneration and ammonium exchange of zeolite in modified SBR process. Water Res. 38,347-354.

5. Karapinar N. 2009. Application of natural zeolite for phosphorus and ammonium removal from aqueous solutions. J. Hazard. Mater. 170, 1186-1191.

6. Kim H.S., Schuler A.J. and Gunsch C.K. 2011. Comparison of Conventional and Integrated FixedFilm Activated Sludge Systems: Attached- and Suspended-Growth Functions and Quantitative Polymerase Chain Reaction Measurements. Water Environ. Res. 83 No. 7 J1, 627-635.

7. Tchobanoglous G., Burton F. and Stensel H.D. 2003. Wastewater Engineering: Treatment and Reuse ( $4^{\text {th }}$ edition), McGraw-Hill Education.

8. Myrzahmetov M.M. and Ospanov K.T. 2011. Ustrojstvo dlja biologicheskoj ochistki stochnyh vod (Installation for biological treatment of wastewater). Patent of the Republic of Kazakhstan No. 2011/0280.1 (18.03.2011).

9. Piaskowski K. and Nowak R. 2012. Study on ammonia nitrogen removal efficiency on selected sorbents (in Polish). Rocznik Ochrony Srodowiska, Vol. 14, 563-571.

10. Ministry of Economic Development and Trade of the Republic of Kazakhstan, 2011. Programma "AK Bulak" poobespecheniju naselenija kachestvennoj pit'evoj vodoj i uslugami vodootvedenijana 2011-2020 gody ('AK Bulak' Programme on providing the population with high quality water supply and sewage disposal services for 2011-2020). Available at: http://adilet.zan.kz/rus/ docs/P1100000570 (accessed 6 August 2014) .

11. Randall C.W., Sen D. 1996. Full-Scale Investigation of an Integrated Fixed-Film Activated Sludge (IFAS) Process for Enhanced Nitrogen Removal. Water Sci. Technol.. 33(12), 155-162.

12. Sriwiriyarat T., Randall C.W. and Sen D.P.E. 2005. Computer Program Development for the Design of Integrated Fixed Film Activated Sludge Wastewater Treatment Processes. J. Environ. Eng., ASCE, Nov. 2005, 1540-1548.

13. Slovcov A.A. 2008. Improvement of biological treatment of wastewater by means of attached biocenoses (in Russian). PhD thesis, Moscow State Univ. of Civil Eng., Russia.

14. Wang S. and Peng Y. 2010. Natural zeolites as effective adsorbents in water and wastewater treatment. Chem. Eng. J. 156, 11-24.

15. Yeon H. J., Chang D., Kim D.W., Kim B.K., Choi J.K., Lim S.Y., Yoon C.Y., Son D.J. and Kim W.Y. 2011. Comparison of Attached Growth Process with Suspended Growth Process. World Academy of Science, Engineering and Technology. Vol. 5, 470-472. 